\title{
HISTORICAL-ASTRONOMIC PROVISION OF BIRTH AND DEATH PROPHET MUHAMMAD SAW
}

\author{
Anisah Budiwati \\ Family Law Study Program (Ahwal Syakhsiyah), Department of Islamic Studies, \\ Faculty of Islamic Studies Univrsitas Islam Indonesia, Yogyakarta \\ anisahbudiwati@uii.ac.id
}

\section{Abstract}

This paper describes the historical aspects of astronomy born from the hijri calendar and its application in determining the date of birth and death of the Prophet Muhammad. This research uses the history-astronomy method, which is history used to discuss important events that were born and died the Prophet Muhammad SAW as a great Islamic figure. While considering astronomy is used to explain the calculation of the start of the hijri calendar and analyze the date of birth and death of the Prophet through the calculation of the hisab Ephemeris and clarification of three software (Accurate Time 5.3.9, Stary Night, and Stellarium). This research concludes the brith of the Holy Prophet SAW on Legi Monday, $14^{\text {th }}$ Rabi'ul Awwal $53 \mathrm{BH}\left(5^{\text {th }}\right.$ May $\left.570 \mathrm{AD}\right)$ and the death that the Prophet Muhammad SAW occurred on Legi Monday, 14 Rabi'ul Awwal 11 H (8 June 632 AD).

Keywords: historical-astronomy; birth and death; the Prophet Muhammad SAW

\section{Abstrak}

Penelitian ini mengurai aspek historis astronomis lahirnya kalender hijriah dan penerapannya dalam penetapan tanggal lahir dan wafat Nabi Muhammad saw. Penelitian ini menggunakan metode pendekatan historis-astronomis yakni sejarah digunakan untuk menelusuri peristiwa penting yaitu lahir dan wafat Nabi Muhammad saw sebagai sebuah biografi tokoh besar Islam. Sedangkan pendekatan astronomi digunakan untuk menjelaskan perhitungan dimulainya kalender hijriah dan menganalisis tanggal lahir dan wafat Rasulullah melalui perhitungan hisab Ephemeris dan klarifikasi tiga software (Accurate Times 5.3.9, Stary Night, dan Stellarium). Penelitian ini menyimpulkan kelahiran Nabi Muhammad saw terjadi pada Senin Legi, 14 Rabi'ul Awwal 53 SH (5 Mei 570 M) dan wafat Nabi Muhammad saw terjadi pada Senin Legi, 14 Rabi'ul Awwal 11 H (8 Juni 632 M).

Kata kunci: historis-astronomis; lahir dan wafat; Nabi Muhammad saw 


\section{A. Introduction}

The calendar is one of the identities of space and time which is a fundamental problem in cosmology ${ }^{1}$. The issue of time and space is an important issue to be investigated for several reasons, first, space and time are very essential and fundamental in their problems with nature, because they are the basic unit that underlies nature. Secondly, the issue of space and time is inseparable from the point of view of matter because modern science considers that the nature of matter means that it cannot be separated fr2om the problem of space and time. ${ }^{2}$ Specifically the Moon used to mark the year as used by the Greek Civilization in defining 12 months in a year and the existence of additional months when needed to adjust the season called the lunisolar calendar. ${ }^{3}$ Likewise with other celestial bodies such as the Sun which is used as a benchmark in the Christian calendar and the Moon which is used as a reference calculation in the lunar calendar.

The existing Islamic history literature does not yet have a conceptual and theoretical analysis of the history of the structuring of the Muslim time system in the past so that the development of theories based on astronomical approaches is needed. During this time the writing or the historiography of Sirah Nabawiyyah presented a full on collection of data, but the conceptual and theoretical formation of such data is often times overlooked. ${ }^{4}$ Thus it is necessary to rewrite the history of the Islamic calendar in an analytical framework that is relevant to the objective reality of the past. The history of astronomical progress is written in some celestial literature, but the problem of the history of important events, especially the birth and death of the Prophet Muhammad has not been analyzed from the astronomical side.

\footnotetext{
${ }^{1}$ Cosmology is science (the branch of astronomy that investigates the origin, structure, and relationship of spacetime of the universe); knowledge about the origin of the Earth's events, their relationship with the Sun system, and the relationship of the Sun system to the universe; science (a branch of metaphysics) that investigates the universe as an ordered system. Look at Heppy El. Rais, Kamus Ilmiah Populer: Memuat Berbagai Kata dan Istilah dalam Bidang Politik, Sosial, Budaya, Sains dan Teknologi, Psikologi, Kedokteran, Pendidikan, Cet. 1. (Yogyakarta: Pustaka Pelajar, 2012), 339.

${ }^{2}$ Joko Siswanto, Orientasi Kosmologi (Yogyakarta: Gadjah Mada University Press, 2005), 63-64.

3 Mitchell Beazley, Philip's Astronomy Encyclopedia: A Comprehensive and Authoritative A-Z Guide to the Universe (London: Octopus Publishing Group, 2002), 65.

${ }^{4}$ Dudung Abdurrahman, Metodologi Penelitian Sejarah Islam (Yogyakarta: Penerbit Ombak, 2011), 59.
} 
The need to know the history of astronomy is basically a Hijri calendar to be able to trace events that occurred in the past to be proven and confirmed with astronomy. During this time there is no minimum level of appreciation of astronomy among jurists and historians about the past history of the mention of the dates so this is a problem in the literature turas in Islam to be dealt with very carefully. ${ }^{5}$ As for one of the results of the research of the great scholar Shaykh Shafiyyurahman Al-Mubarakfuri ${ }^{6}$ and astronomy researcher Mahmud Pasya ${ }^{7}$ the date of birth of the Prophet, for example, is mentioned in Mecca on Monday morning, $9^{\text {th }}$ Rabī'ul Awwal, the beginning of the year of the Elephant Event, and forty years after the rule of Kisra Anusyirwan, or coincides with the $20^{\text {th }}$ or $22^{\text {nd }}$ April of $571 \mathrm{AD}^{8}$ This statement is very different from the majority of general knowledge which states that the Prophet's birthday is commemorated every $12^{\text {th }}$ of Rabî'ul Awwal as stated in the calendars circulating in Indonesia. If we look at the historical treasures and the proclamation of hadis, there is no clarity and uniformity regarding the figure when the Prophet Muhammad was born. Among the figures who agreed on $12^{\text {th }}$ Rabi'ul Awwal namely Ibn Ishaq ${ }^{9}$, but the extent of the truth of this number needs to be tested through historical and astronomical reconstruction. ${ }^{10}$ Thus, this paper describes the historical aspects of astronomy from the birth of the Islamic calendar and its application in determining the date of birth and death of the Prophet Muhammad.

\section{B. Research Method}

\footnotetext{
${ }^{5}$ Syamsul Anwar, Interkoneksi Studi Hadis Dan Astronomi (Yogyakarta: Suara Muhammadiyah, 2011), 167.

${ }^{6}$ Syaikh Shayifurrahman Mubarakfury adalah juara 1 pemenang lomba penulisan Sīrah Rabitah Alam AlIslami.

${ }^{7}$ Mahmud Pasya was an Egyptian astronomer in $1302 \mathrm{H}$. He examined the date of birth of the Prophet using the solar eclipse that occurred during the time of the Prophet Muhammad and then counted back to the year, month and day the Prophet was born.

8 Syaikh Shafiyyurrahman Al-Mubarakfuri, Ar-Rahiq Al-Maktum Bahtsun Fis Siratin Nabawiyyat 'ala Shahibiha Afdhalush Shalati Was Sallam (Beirut: Dar Ehia Al- Tourath Al-Arabi, n.d.), 103.

${ }^{9}$ Muhammad bin Ishaq bin Yasar was the first Muslim historian who was born in $85 \mathrm{AH} / 704$ AD and died in $151 \mathrm{AH} / 768 \mathrm{AD}$ He was a tabi'in who wrote Sirat Rasulullah, the first most comprehensive biography of Rasulullah. His work was then continued and perfected by the next generation, Abu Muhammad Abdul Malik, known as Ibn Hisham.

${ }^{10}$ Butar-Butar, Esai-Esai Astronomi, 64.
} 
This study uses a historical-astronomical approach as a methodological consequence when uncovering past events. ${ }^{11}$ The historical approach is used to trace the day and date of events in Islamic literature to retrieve the key information of historical time related to the birth and death of the Prophet Muhammad.

The astronomical approach is used to explain the calculation of the start of the hijri calendar and analyze the date of birth and death of the Prophet through the calculation of the Ephemeris hisab and clarification of three softwares (Accurate Times 5.3.9, Stary Night, and Stellarium).

Some things that become a limitation in research are:

1) Markaz of this calculation is the coordinate point of Masjidil Haram, Mecca which is $21^{\circ} 25^{\prime} 21.17^{\prime \prime} \mathrm{N}$ and $39^{\circ} 49^{\prime} 34.56^{\prime \prime} \mathrm{E}^{12}$ with a height of 361 meters and the Nabawi Mosque, Medina (24 28' 1.83" N and 39 36' 40.07" E) with a height of 967 meters. $^{13}$

2) Criteria for determining the beginning of the month, namely imkān ar-rukyat of Ministry of Religion of the Republic of Indonesia ${ }^{14}$ and hisāb hakiki wujūd al-hilāl. ${ }^{15}$

3) Software calculation and simulation of celestial bodies in this study is Accurate Times 5.3.9, Stary Night, Stellarium and Ephemeris Hisab Rukyat.

\footnotetext{
${ }^{11}$ As mentioned in the book Metode Studi Islam that discussing past events means opening two methodological implications, first it is imperative to use a more oriented method of historical study. Second, the explanation and analysis of history based on social-scientific analysis. Look at Faisar Ananda Arfa, Syafruddin Syam, and Muhammad Syukri Albani Nasution, Metode Studi Islam : Jalan Tengah Mencari Islam (Depok: PT. Raja Grafindo Persada, 2015), 133-134.

${ }^{12}$ The results of Ahmad Izzuddin's research on the central point of the Kaaba using a handheld GPS. Look at Ahmad Izzuddin, Ilmu Falak Praktis (Metode Hisab-Rukyat Praktis dan Solusi Permasalahannya) (Semarang: PT. Pustaka Rizki Putra, 2012), 30. In addition, there are differences in the coordinates of the Kaaba by 15 versions in minutes and seconds. Look at Susiknan Azhari, Ilmu Falak: Perjumpaan Khazanah Islam dan Sains Modern (Yogyakarta: Suara Muhammadiyah, 2004), 206.

${ }^{13}$ Data is taken from Google Earth Software by the author on 10 November 2018 with information on imagery date 14 October 2018.

${ }^{14}$ The Indonesian Government's criteria in determining the beginning of the lunar month other than Ramadan, Shawwal and Żulhijjah based on reckoning (hilal height $+2^{\circ}$ or 8 month age between the time of ijtima 'and gurub). Look at Kemenag, Ephemeris Hisab Rukyat 2019 (Jakarta: Direktorat Urusan Agama dan Pembinaan Syariah Direktorat Jendral Bimas Islam Kementerian Agama RI, 2019), 405.

${ }^{15}$ Hisab hakiki wujudul hilal, namely the reckoning of the new lunar moon, starts when three criteria have been met: 1) ijtima (conjunction) has occurred, 2) ijtima (conjunction) occurs before sunset, and 3) at sunset the discs over the Moon are above horizon (new moon has come into being). Look at Majelis Tarjih dan Tajdid PP Muhammadiyah, Pedoman Hisab Muhammadiyah (Yogyakarta: Majelis Tarjih dan Tajdid PP Muhammadiyah, 2009), 78.
} 
Data analysis techniques using the hisab 'urfi (masehi-hijri conversion program) is hisab urfi Slamet Hambali ${ }^{16}$ for date conversion, name of the day and five-day a week (pasaran) ${ }^{17}$ and hisab hakiki Ephemeris ${ }^{18}$. In addition, three software is used to provide data calculation and simulation of the position of celestial bodies together, namely Accurate Times 5.3.9 ${ }^{19}$, Stary Night ${ }^{20}$, and Stellarium ${ }^{21}$.

\section{Discussion}

\section{C.1. Determination of Birth's Date of the Prophet Muhammad}

In this research, Islamic literature related to the birth of the Prophet includes the Qur'an, Hadis and Tafsir also several books. In al-Qur'ān, the birth of the Prophet Muhammad is not mentioned explicitly although al-Qur'ān is a source of historical information of the Prophet Muhammad, his life and mission ${ }^{22}$. In line with Maurice in his dissertation that although al-Qur'an does not bring to light the details of the chronology of data, but its function still underlines all sources. ${ }^{23}$ There is one surah which is related to the time of the birth of the Prophet, namely the coming of the elephant's army to destroy the Kaaba, namely Al-Finl, where this letter is explained further in the tafsir explanation.

\footnotetext{
${ }^{16}$ Slamet Hambali, Almanak Sepanjang Masa: Sejarah Sistem Penanggalan Masehi, Hijriyah dan Jawa, ed. Abu Rokhmad (Semarang Indonesia: Program Pascassarjana IAIN Walisongo, 2011), 45-50 dan 66-68. Comparison with the results of an interview with Slamet Hambali on June 24, 2019 in Building C.10 Campus 1 of Postgraduate Program UIN Walisongo Semarang.

${ }^{17}$ Pasaran is the completeness of the Islamic Javanese Calendar created by Sultan Agung as a fusion of the Saka Year Calendar with the Hijriyah Year. Pasaran consists of five namely kliwon, legi, pahing, pound and wage, always included in a calendar because of the needs of the community especially Central Java, Yogyakarta and surrounding areas which in general in every important activity often includes market days. Look at Jannah, Kalender Hijriyyah-Masehi 150 Tahun: 1364-1513 H (1945-2090 M), v.

${ }^{18}$ Kemenag, Ephemeris Hisab Rukyat 2019 (Jakarta: Direktorat Urusan Agama dan Pembinaan Syariah Direktorat Jendral Bimas Islam Kementerian Agama RI, 2019), 427.

19 Mohammad Odeh, “Islamic Cresents' Observation Project,” 2013, http://www. icoproject.org/accut.html \%0A, accessed November 12, 2018.

${ }^{20}$ John Mosley, "Stary Night Pro Plus" (Canada: Imaginova Crop, 2004), www.starynight.com, accessed November 12, 2018.

${ }^{21}$ Matthew Gates, "Stellarium" (USA: Free Software Foundation, Inc, 2000), http://www.stellarium.org, diakses pada 12 November 2018.

${ }^{22}$ Hussam Almujalli, "The Relationship between the Prophet Muhammad and the Quran," Journal of Islamic Studies and Culture 2, no. 4 (2014): 1-5, https://doi.org/10.15640/jisc.v2n4a1.

${ }^{23}$ Maurice A. McPartlan, "The Contribution of Qur' an and Hadit to Early Islamic Chronology" (Disertasi, University of Durham, 1997), 103.
} 
The Qur'ān mention to the figure of the Prophet Muhammad, but only touches on global information such as the Quraish Shihab classifying, one of them in pre-prophetic times, Muhammad is a Prophet known by Jews and Christians in Al-A'raf verse 157 and Al-Baqarah verse 146, an orphan in Ad-Duha verses 6-8, and someone who is ummi (never read a book or write a word before the revelation of the Qur'an) in Al-Ankabut verse 48. ${ }^{24}$

The birth of the Prophet in the hadith was mentioned to by looking at the hadis narrated by Qatadah RA. ${ }^{25}$ It was explained when the Prophet was asked about Monday, the Prophet replied that on that day was the day I was born, the day I was sent, and the day I was given a revelation. Monday as the birthday of the Prophet was popular and became an agreement among the scholars. Other traditions mention that the emigration of the Prophet from Mecca and arrived in the city of Medina on Monday. ${ }^{26}$

Then look at the interpretation of the Qur'an, the study of the birth of the Prophet is related to the interpretation of Surah Al-Finl, in which Allah has acted against the army of troops (a person who has an elephant named Mahmud and his friends, namely the King of Yemen named Abraha). It was this King Abraha who built a Church in Shan'a with the aim that people should turn away from pilgrimage to Mecca. Abraha's attack on Mecca was motivated by the presence of a man from Kinanah who smeared the part of the Church that was made a mecca with Camel dung with the intention of humiliating him, so Abraha vowed to destroy the Kaaba. When they moved to destroy the Kaaba, Allah destroyed his army with a group of birds carrying groups made of burning clay. ${ }^{27}$

Tafsir Al-Misbah mentions the extraordinary event as above as the beginning of the calendar they called the Year of the Elephant and it was this year that the

\footnotetext{
${ }^{24}$ M. Quraish Shihab, Wawasan Al-Qur'ān: Tafsir Tematik Atas Pelbagai Persoalan Umat (Bandung: Mizan Media Utama, 2007), 56-59.

${ }^{25}$ Abul Husain Muslim bin al-Hajaj Naisaburi, Shahih Muslim (Beirut: Dar al-Fikr, n.d.), Juz 3, 167.

${ }^{26}$ Abu, Al-Jami' Al-Shahih Al-Mukhtashor, Juz 3, 1421.

${ }^{27}$ Bachtiar Nasir, Tadabur Al-Qur'ān Panduan Hidup Bersama Al-Qur'ān (Jakarta: Gema Insani, 2016), 488. 489.
} 
Prophet Muhammad was born. Another opinion says this event occurred 23 years or 40 years before the birth of the Prophet, but the first opinion is the most popular. ${ }^{28}$ Whereas if you look at other Quraish Shihab interpretations that specifically address the Sirah Nabawiyyah, he often includes quotations of information related to differences in the date of birth of the Prophet. He stated that the difference of opinion concerning the birth of the Prophet Muhammad and not just on the day and month of his birth and whether at night or early in the day, but also in the birth year.

Birth's Date of the Prophet which is popular is 12 Rabi' al-Awwal, the ethics falls on a Monday night to coincide with the August 29, 580 AD. Al-Mas'udi, one of Historian assesses that the birth of the Prophet occurred fifty days after the presence of the troop forces whose presence at that time coincided with Monday, 13 Muharram and approaching to Mecca 17 Muharam, so as such, still according to Al-Mas'udi, the birth of the Prophet Muhammad. happened on the $8^{\text {th }}$ Rābi'ul Awwal. Birth of the prophet Muhammad born on Monday supported by hadis narrated by Imam Muslim. ${ }^{29}$

Quraish Shihab also included information that Mahmud al-Falaki Al Mashry, an expert in Egyptian astronomy, was quoted by Ali Husni Al-kharbuthli in his book Abdul Muttalib Jad ar-Rasul stipulating that the Prophet Muhammad born on the $55^{\text {th }}$ day after the defeat of the invading army, namely on the morning of 9 Rabbi al-Awwal in AD 571. Some also suspect his birth in Ramadan, or Muharram or Rajab. ${ }^{30}$

Book written by A. Syalabi, born of the Prophet on 9 or 12 Rabī'ul Awwal $\left(\text { April } 20^{\text {th }}, 571\right)^{31}$, whereas according to Wafiyah it was mentioned in $570 \mathrm{AD}^{32}$ In

${ }^{28}$ M. Quraish Shihab, Tafsir Al-Misbah: Pesan, Kesan, dan Keserasian Al-Qur'ān, Vol. 15 (Jakarta: Lentara Hati, 2009), 617.

${ }^{29}$ M. Quraish Shihab, Membaca Sìrah Nabi Muhammad Saw dalam Sorotan Al-Qur'ān dan Hadits-Hadits Shahih, Cet. ke- (Jakarta: Lentara Hati, 2014), 210.

${ }^{30}$ Shihab, 211.

${ }^{31}$ A. Syalabi, Sejarah dan Kebudayaan Islam 1 (Jakarta: Pustaka Al Husna Baru, 2003), 71.

${ }^{32}$ Wafiyah, Sìrah Nabawiyah (Yogyakarta: Ombak, 2013), 32. 
the Sirah Nabawiyyah written by Shafiyyurrahman Al-Mubarakfuri, the birth of the Prophet Muhammad was mentioned in detail on Monday morning $9^{\text {th }}$ Rabi'ul Awwal, the beginning of the year of the Elephant Event and forty years after Kisra Anusyirwan's rule, or coincided with the date $20^{\text {th }}$ or $22^{\text {nd }}$ April 571 AD. ${ }^{33}$

In contrast to Sīrah Nabawiyah by Ibn Ishaq who mentions $12^{\text {nd }}$ Rabi'ul $\mathrm{Awwal}^{34}$ which is the same as the book of Acts 25 of the Prophet and Apostle, namely born in Mecca, Monday $12^{\text {nd }}$ Rabi'ul Awwal elephant year $\left(20^{\text {th }}\right.$ Nisaan 571 $\mathrm{AD})$. It was stated in the book that the year of the Elephant in question was the arrival of an elephant army led by Abrahah from the land of Habasyah to bring down the Kaaba. Their evil intentions were towarted by the help of God who sent Ababil birds, who dropped stones containing plague and inflicted upon Abraha's army. ${ }^{35}$ Whereas in the book written by Muhammad Ali Rohmad, entitled Portrait of Islamic Thought and Civilization only lists the birth of the Prophet on the 12th of Rabi'ul Awwal to coincide with the 29th of August ${ }^{36}$ and in the Encyclopedia of Muhammad as the Prophet referred to coincide with August $2^{\text {nd }}, 570$ AD. $^{37}$ However, the conversion of the date is too far off to say so, because the majority declared April.

The Book of Sirah Nabawiyah Ibn Hisham, his reference citing Ibn Ishaq, who was the author of a wal who was referred to by later writers, mentions the date of the Prophet's birth on $12^{\text {nd }}$ Rabbi al-Awwal. ${ }^{38}$ From this information it is natural that in the end the authors of the Sirah of the Prophet and Islamic history in general undertook a history search with different methods and results. ${ }^{39}$ Including the opinion of the Prophet Muhammad born in 570 as the opinion of Caussin de

33 Syaikh Shafiyyurrahman Al-Mubarakfuri, 103.

${ }^{34}$ Ibnu Ishaq, The Life of Muhammad, ed. A. Guillaume (New York: Oxford University Press, 1967), 69.

${ }^{35}$ Zaid Husen Hamid, Kisah 25 Nabi dan Rasul (Jakarta: Pustaka Amani, 1995), 135.

${ }^{36}$ Muhammad Ali Rohmad, Potret Pemikiran dan Peradaban Islam (Yogyakarta: Kaukaba Dipantara, 2015), 80.

${ }^{37}$ Afzalur Rahman, Ensiklopedi Muhammad Sebagai Nabi (Bandung: Pelangi Mizan, 2009), 23.

${ }^{38}$ Abu Muhamad Abdul Malik bin Hisyam Al-Muafiri, Sīrah Nabawiyah Ibnu Hisyam Jilid I, ed. terj. Fadhli Bahri (Beirut: Darul Fikr, 1994), 131.

${ }^{39}$ Syamsul Bakri, Peta Sejarah Peradaban Islam (Yogyakarta: Fajar Media Press, 2011), 17. 
Perceval quoted by Muhammad Husain Haekal ${ }^{40}$ and others say the Prophet was born in $571 .^{41}$

Other Islamic literature such as a book called Dalail an-Nubuwwah discusses the birth of the Prophet (chapter days, months, and years) with reference to the hadith and the history book of Ibn Hisham, which explains that the Prophet was born on Monday based on Muslim traditions in the chapter of Fasting and Hadith from Musnad Imam Ahmad. Then the month of birth of the Prophet mentioned in Rabi' al-Awwal night to 12, based on the Sirah Nabawiyah Ibn Hisham. Furthermore, the year of the birth of the Prophet is after 25 years from the year of the Elephant and other information mentions 40 years after the year of the Elephant. $^{42}$

In the book with the tittle Sejarah Arab Pra-Islam the reasons for naming the years that occur generally occur in Arab society. The naming of the year Elephant is because the Arab community at that time marked the year with major events that were considered large, besides known ways to mark the year as in the existing Jahiliyah manuscripts. Al-Mas'udi explained that pre-Islamic Arabs marked the year in many ways, including those guided by the reign of previous kings, events that were considered great, and days of war. As the opinion of Tabari in the book of Sejarah Arab Pra-Islam (Arabic History Before Islam) it is said that the Arabs did not determine the number of years until the advent of Islam, except the Quraysh tribe which determined the number of years before Islam with reference to the year of the Elephant. Until then other Arab tribes also referred to their historic days of war. $^{43}$

${ }^{40}$ Muhammad Husain Haekal, Sejarah Hidup Muhammad, Cet. ke-2 (Jakarta: PT. Mitra Kerjaya Indonesia, 2003), 49.

${ }^{41}$ Sami bin Abdullah bin Ahmad Maghluts, Athlas Ta>rikh Al-Anbiya Wa Ar-Rusul, ed. Terj. Qasim Shaleh, Cet. ke-2 (Jakarta: Almahira, 2009), 310.

42 Abu Bakar Ahmad bin Husain Baihaqi, Dalail An-Nubuwwah Wa Ma'rifatu Ahwal Shohibi as-Syarifah (Beirut Libanon: Dar al-kutubal-alamiyah, 2002), 71-78.

${ }^{43}$ Jawwad Ali, Sejarah Arab Sebelum Islam (Geografi, Iklim, Karakteristik, dan Silsilah), terj. Khalifurrahman Fath, (Tangerang: PT Pustaka Alvabet, 2018), 40. 
According to Hideyuki Ioh, the expedition of the King of Abrahah Elephant army to Mecca was estimated to occur in the middle of the $6^{\text {th }}$ century when the pilgrimage season fell in the spring. ${ }^{44}$ Likewise, according to Ahmed Abu Zayd, in his correction of Islamic encyclopedias, it was stated that the majority of Ulama stated that the birth of the Prophet Muhammad took place in the year of the Elephant, as confirmed by a recent study by Muslim and Orientalist researchers who found that the Elephant year coincided with 570-571 AD. ${ }^{45}$

Then astronomical literature such as the book Nurul Anwar by KH. Noor Ahmad explained the date of birth of the Prophet based on hisab 'urfi, istislahi and hisab ijtim $\bar{a}$, the book Almanac of All Time written by Slamet Hambali ${ }^{46}$, and also Jean Meeus in his astronomical tables ${ }^{47}$, showing the different birth dates of the Prophet including $8^{\text {th }}, 9^{\text {th }}$, and $10^{\text {th }}$ Rabi'ul Awwal $53 \mathrm{BH}$. Another Islamic astronomer, Salamun Ibrahim, mentions $20^{\text {th }}$ April 571 AD. ${ }^{48}$

According to the hisab KH. Noor Ahmad that the Prophet Muhammad was born in Monday Legi, 10 ${ }^{\text {th }}$ Rabi'ul Awwal $-53 \mathrm{H}$ based on ijtimā results in the month of Rabi'ul Awwal $-53 \mathrm{H}^{49}$ In contrast to the writings of Arwin Juli ButarButar which mentions the date of birth of the Prophet $9^{\text {th }}$ Rabi'ul Awwal based on the results of his reconstruction through comparison of the opinions of scholars and jumhur scholars who mention Monday ${ }^{50}$, while Thomas Djamaluddin agreed with the opinion that the birth of the Prophet was Monday, $12^{\text {th }}$ Rabi' 1 ul Awwal year

\footnotetext{
${ }^{44}$ Hideyuki Ioh, “The Calendar in Pre-Islamic Mecca," Arabica 61 (2014): 471-513, 496.

${ }^{45}$ Ahmed Abu Zayd, The Life of The Prophet: Correction of The Fallacies in the Encyclopedia of Islam (Morocco: ISESCO, 2003), 36.

${ }^{46}$ Slamet Hambali, Almanak Sepanjang Masa: Sejarah Sistem Penanggalan Masehi, Hijriyah dan Jawa, ed. Abu Rokhmad (Semarang Indonesia: Program Pascassarjana IAIN Wallisongo, 2011), 111-112.

${ }^{47}$ Jean Meeus, Astronomical Tables of the Sun, Moon, and Planets (USA: Willmann-Bell, Inc, 1983), 74-75.

${ }^{48}$ Salamun Ibrahim, Ilmu Falak: Cara Mengetahui Awal Bulan, Awal Tahun, Musim, Kiblat dan Perbedaan Waktu, Cet. ke-3 (Surabaya: Pustaka Progressif, 2003), 78.

${ }^{49}$ Noor Ahmad, Risalah Al-Falak Nur Al-Anwar (Kudus: Madrasah TBS, 1986), 31.

${ }^{50}$ Butar-Butar, Esai-Esai Astronomi, 66.
} 
of the Elephant which coincided with May $5^{\text {th }}, 570$ AD based on the results of calculating the conversion software. ${ }^{51}$

Based on the above data, three keywords were chosen, namely Monday (indicated by the authentic hadith about the birth of the Prophet), the month of Rabi'ul Awwal (interpretation strengthened by history in the Sirah Nabawiyyah) and the year of the Elephant (the interpretation of the year of the Elephant from the interpretation reinforced by $\mathrm{AD} 570$ or 571 in the book of history). From this information, a countdown of the birth of the Prophet was carried out in the following stages:

a. Convert the predicted date of the birth of the Prophet i.e. May 5570 AD (Monday Legi, 12 Rabi'ul Awwal 53 BH)

b. Determine the beginning of the month Rabi'ul Awwal $53 \mathrm{BH}$ by looking at the data ijtimā time and Hilal position in Mecca, as follows:

Table 1.

Data on the cresent position of Rabi'ul Awwal $53 \mathrm{BH}$ in Mecca

\begin{tabular}{lllll} 
& Ephemeris & $\begin{array}{l}\text { Accurate Times } \\
5.3 .9\end{array}$ & Stary Night & Stellarium \\
\hline \multirow{2}{*}{ ijtimā time } & Monday, Apr 21 & Monday, Apr 21 & Monday, Apr 21 & Monday, Apr 21 \\
& 570 at 09.18 LT & 570 at 07.59 LT & 570 at 05.17 LT & 570 at 05.17 LT \\
\hline Moon Alt & $+03^{\circ} 26^{\prime} 14.61^{\prime \prime}$ & $+02^{\circ} 51^{\prime} 41^{\prime \prime}$ & $+03^{\circ} 37^{\prime} 50.52^{\prime \prime}$ & $+03^{\circ} 41^{\prime} 01.6^{\prime \prime}$ \\
\hline Moon age & $0^{\mathrm{j}} 25^{\mathrm{m}}$ & $13^{\mathrm{j}} 11^{\mathrm{m}}$ & $12^{\mathrm{j}} 56^{\mathrm{m}} 39^{\mathrm{d}}$ & $13^{\mathrm{j}} 03^{\mathrm{m}} 36^{\mathrm{d}}$ \\
\hline Elongation & & $04^{\circ} 43^{\prime} 02^{\prime \prime}$ & $04^{\circ} 36^{\prime} 37^{\prime \prime}$ & $4^{\circ} 39^{\prime} 23.5^{\prime \prime}$ \\
\hline
\end{tabular}

From the four calculations above, the data show that the tendency of three of the four calculations shows that the results meet the Hilal visibility criteria of the Ministry of Religion of the Republic of Indonesia as well as the criteria for the hilal form so that the beginning of the month of Rabi'ul Awwal $53 \mathrm{BH}$ falls on Tuesday, April 22, 570 M.

\footnotetext{
${ }^{51}$ Thomas Djamaluddin, "Konsistensi Astronomis Kalender Hijriah," 2010, https://tdjamaluddin. wordpress.com/2010/04/23/konsistensi-historis-astronomis-kalender-hijriyah/, diakses pada tanggal 1 November 2018.
} 
c. Ensure and simulate the calendar month of Rabi'ul Awwal $53 \mathrm{BH}$ in the table compiled by the Gregorian calendar conversion.

Table 2.

Calendar April-May 570 M / Rabi al-Awwal 53 BH

April - May 570 AD / Rābi’ul Awwal 53 BH

\begin{tabular}{lllllll}
\hline Mo & Tu & We & Th & Fr & Sa & Su \\
\hline 14 & 15 & 16 & 17 & 18 & 19 & 20
\end{tabular}

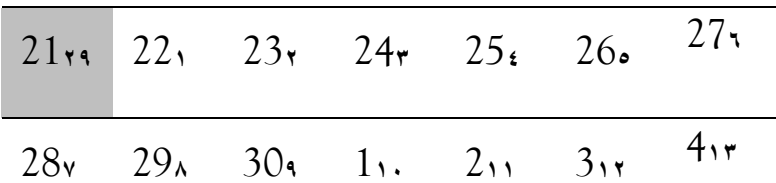

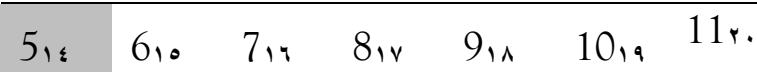

12r) 13rr 14rr 15rs 16ro 17 rr 18 rr

From the table above it is known that according to the hisab hakiki contemporary, the birth of Prophet Muhammad Holy fell on Monday, $5^{\text {th }}$ May 570 AD coincided with the $14^{\text {th }}$ Rabi al-Awwal $53 \mathrm{BH}$.

\section{C.2. Determination of Death's Data of the Prophet Muhammad}

From the many sources that mention the death's date of the Prophet Muhammad can be explained from several sources as follows. The information given by Quraish Shibab in Tafsir Al-Misbah is related to the death of the Prophet when he tells about the confusion of the people regarding the condition of the Holy Prophet. that just disappear after Sayyidina Abu Bakar straighten alleged., after he saw with his own eyes the remains and the circumstances of the Prophet. Meanwhile the expert said that Abu Bakr's belief in his death was obtained after seeing signs of change in his body. This event is the peak of summer, which is June. Tuesday $13^{\text {rd }}$ Rabī'ul Awwal in $11 \mathrm{H}$ or $9^{\text {th }}$ June $632 \mathrm{AD}$, or Wednesday 14 Rabī'ul Awwal, that is, after Sayyidina Abu Bakr's explanation, the Prophet was bathed with water taken from a well which he often bathed and drank his water. Then he was 
shrouded with three pieces of cloth. The one who bathed him was Ali bin Abi Talib with his wife and the son of his adopted son, Usamah. Another narration states that he also gave a bath to a resident of Medina (Ansar), namely Aus bin Khauly. Al-Fadl, son of the Prophet's uncle al 'Abbas hug him when washed. ${ }^{52}$

Hisyam's hadith statement, narrating Ikrimah from Ibn Abbas said that the Messenger of Allah was sent for 40 years, lived in Mecca for 13 years then he was ordered to migrate to Medina for 10 years, then die at the age of 63 years as follows:

$$
\begin{aligned}
& \text { حدثنا مطر بن الفضل حدثنا روح بن عبادة حدثنا هشام حدثنا عكرمة عن ابن عباس رضي الله } \\
& \text { عنهما قال :بعث رسول الله صلى الله عليه و سلم لأربعين سنة فمكث بمكة ثناث عشرة سنة } \\
& \text { يوحى إليه ثم أمر بالهجرة فهاجر عشر سنين ومات وهو ابن ثلاث وستين }
\end{aligned}
$$

"Mathar Bin Al-Fadl reported to us, Rūh Bin Ubada reported to us, Hisham reported us, Ikrama told us about Ibn Abbas RA, he said: He sent the Messenger of Allah (saw) for forty years then he stayed in Mecca for thirteen years, revealed to him to emigrate then Rasulullah migrated for ten years and Rasulullah died at the age of sixty-three years."

Information quoted in Fathul Bari, where the Prophet died on Monday, at which time the Prophet did not lead the morning prayer with the Muslims. In the book Fathul Bari reviewed the difference in opinion of the death of the Prophet between the time of the duha and the others said it happened when the Sun was leaning towards the west. ${ }^{54}$ This statement is also mentioned in the hadith when Aisha was asked the day when the Messenger of Allah died, that is:

$$
\begin{aligned}
& \text { حدثنا معلى بن أسد حدثنا وهيب عن هشام عن أبيه عن عائشة رضي الله عنها قالت : دخلت } \\
& \text { على أبي بكر رضي الله عنه فقال في كم كفنتم البي صلى الله عليه و سلم ؟ قالت في ثلاثة } \\
& \text { أثواب سحولية ليس فيها قميص ولا عمامة ـ وقال لها في أي يوم توفي رسول الله صلى الله عليه } \\
& \text { و سلم ؟ قالت يوم الإثنين }
\end{aligned}
$$

\footnotetext{
${ }^{52}$ Shihab, Membaca Sirah Nabi Muhammad Saw dalam Sorotan Al-Qur'an dan Hadits-Hadits Shahih, 1117.

${ }^{53}$ Al-Bukhari, Al-Jami' As-Shahih Al-Mukhtashar, No. 3689, Juz 3, 1416.

${ }^{54}$ Ibnu Hajar Al Asqalani, Fathul Bari, terj. oleh Amiruddin, (Jakarta: Pustaka Azzam, 2007), 489-490.

${ }^{55}$ Al-Bukhari, Al-Jami’ As-Shahih Al-Mukhtashar, No. 1321, Juz 1, 467.
} 
"Muala bin Asad told us: Wahib told us from Hisham, from his father, from Ayesha ra, he said: I went to see Abu Bakr ra, he said: how many (layers) do you shroud a body of the prophet peace be upon him? She (Aisyah) said: 3 layers of fabric from Sahuli, without robe and turban. He (Abu Bakr) said to him: what day did the Prophet die? She said: Monday. "

Tafsir Ibn Kathir quoted the opinion of Ibn Jarir and several other scholars about the event of the death of the Prophet after the day of Arafah, which is after 81 days. On the day of Arafah coincided with the decline in Al-Maidah verse 3 which at the time was the sermon of the Prophet Muhammad on the great (hajj) pilgrimage. Al-Maidah verse 3 is a verse that was revealed on the day of Arafah, and after that there are no more verses that go down concerning halal and haram. Then Rasulullah returned and after that died. ${ }^{56}$

History book Philip K. Hitti mentions the death of the Prophet occurred in the year $10 \mathrm{H}$, which is three months ${ }^{57}$ After returning to Medina the Prophet Muhammad fell ill and died of a headache on 8 June $632 .{ }^{58}$ Other information states that the Prophet's death occurred just at the time of Duha, Monday 12 Rabi'ul Awwal 11 Hijri. At that time he died at the age of 63 years over 4 days. ${ }^{59}$ In line with the opinion of Badri Yatim who stated that on Monday, the 12th of Rābi'ul Awal $11 \mathrm{H} / 8$ June 632 AD the Prophet Muhammad died at the home of his wife Aisyah. ${ }^{60}$

Thomas Djamaluddin in his writings provide clarification through astronomical analysis in which the last days of the life of the Prophet were marked by the decline in Al-Maidah verse 3 which states that Allah has perfected the religion of Islam and praised it. This verse came down when wuquf in Arafah 9 Zulhijjah $10 \mathrm{H}$ which coincided with Friday, March 6, 632. Three months after the

\footnotetext{
${ }^{56}$ Abdullah bin Muhammad bin 'Abdurrahman bin Ishaq Alu Syaikh, Tafsir Ibnu Katsir Jilid 3 (Bogor: Pustaka Imam Asy-Syafi’i, 2004), 19.

${ }^{57}$ dalam Ensiklopedi Muhammad sebagai Nabi disebut dua bulan setelah kembali dari perjalanan haji, Nabi jatuh sakit dan wafat pada Senin, 12 Rabīu'l Awwal pada tahun 11 H (23 tahun setelah kenabian) yang bertepatan dengan Juni 633 M. Look at Rahman, Ensiklopedi Muhammad Sebagai Nabi, 48.

${ }^{58}$ Hitti, History of the Arabs: From the Earliest Times to the Present, 150.

${ }^{59}$ Al-Maghluts, Atlas Agama Islam: Menelusuri Bukti-Bukti Konkret yang Mengungkapkan Kemuliaan dan Kebenaran Islam Melalui Peta dan Foto, 94.

${ }^{60}$ Yatim, Sejarah Peradaban Islam, 33.
} 
fall of this verse the Messenger of Allah died on 12 Rabbi al-Awwal $11 \mathrm{H}$. Astronomical analysis states that 12 Rabbi al-Awwal should fall on Saturday, June 6, 632, but many believe that the Prophet died on Monday, which means on June 8, $632 \mathrm{AD}$ This difference cannot be explained due to the istikmal. ${ }^{61}$

\section{Conclusion}

Based on the analysis of the available Islamic sources, three key words are obtained, namely Monday, Rābi'ul Awwal, and 11 AH. To trace when the Prophet's death was based on the historical data above, the following steps were carried out:

1. Convert the date of the Prophet's death on Monday Legi, 14 Rabi'ul Awwal $11 \mathrm{H}$ (8 June 632 AD)

2. Determine the beginning of the month using the Hilal visibility criteria by looking at ijtimā ' time data and Hilal's position in Mecca, as follows:

Table 3.

The Position of the New Moon of Rabī'ul Awwal Month $11 \mathrm{H}$ in Medina

\begin{tabular}{|c|c|c|c|c|}
\hline & Ephemeris & $\begin{array}{l}\text { Accurate } \\
\text { Times 5.3.9 }\end{array}$ & Stary Night & Stellarium \\
\hline Ijtimā time & $\begin{array}{l}\text { Sun, May } 24 \\
632 \text { at } 13.46 \\
\text { LT }\end{array}$ & $\begin{array}{l}\text { Sun, May } \\
24632 \text { at } \\
22.38 \mathrm{LT}\end{array}$ & $\begin{array}{l}\text { Sun, May } 24 \\
632 \text { at } 22.45 \\
\text { LT }\end{array}$ & $\begin{array}{l}\text { Sun, } 24 \text { May } 632 \\
\text { at } 22.19 \text { LT }\end{array}$ \\
\hline Moon Alt & $-01^{\circ} 25^{\prime} 2.85^{\prime \prime}$ & $-02^{\circ} 46^{\prime} 19^{\prime \prime}$ & $-01^{\circ} 49^{\prime} 42^{\prime \prime}$ & $-01^{\circ} 03^{\prime} 09.6^{\prime \prime}$ \\
\hline Moon age & $05^{\mathrm{h}} 18^{\mathrm{m}}$ & $-03^{\mathrm{h}} 31^{\mathrm{m}}$ & $-03^{\mathrm{h}} 43^{\mathrm{m}} 55^{\mathrm{s}}$ & $-03^{\mathrm{h}} 39^{\mathrm{m}} 16^{\mathrm{s}}$ \\
\hline Elongation & - & $04^{\circ} 10^{\prime} 23^{\prime \prime}$ & $04^{\circ} 15^{\prime} 03^{\prime \prime}$ & $04^{\circ} 13^{\prime} 31.4^{\prime \prime}$ \\
\hline
\end{tabular}

From the calculation of the four calculations above, it was concluded that the beginning of the month Rabi'ul Awwal $11 \mathrm{H}$ fell on Tuesday, May 26, $632 \mathrm{AD}$.

61 Thomas Djamaluddin, “Konsistensi Historis-Astronomis Kalender Hijriyah,” 2010, https://tdjamaluddin.wordpress.com/2010/04/23/konsistensi-historis-astronomis-kalender-hijriyah/., diakses pada 21 September 2018. 
3. Ensure and simulate the calendar of the month of Rābi'ul Awwal in the table arranged by adjusting the conversion of the Christian calendar.

Table 4 .

Calendar of May-June 632 CE / Rābi'ul Awwal 11 H

\begin{tabular}{|c|c|c|c|c|c|c|}
\hline \multicolumn{7}{|c|}{ May - Juni 632 AD/ Rābi'ul Awwal 11 H } \\
\hline Mo & $\mathrm{Tu}$ & We & Th & $\mathrm{Fr}$ & $\mathrm{Sa}$ & $\mathrm{Su}$ \\
\hline & & & & & & $24 r a$ \\
\hline $25 r$. & 261 & $27 r$ & 28 & 29 ؛ & 30. & 31 r \\
\hline $1 v$ & $2 \wedge$ & $3 a$ & 41. & 511 & 6ir & 7 ir \\
\hline $81:$ & 910 & 1014 & 11 iv & $12, \wedge$ & 1319 & $14 r$. \\
\hline $15^{r}$ & $16 r$ & $17 r r$ & 18 \& & 19 ro & $20 r 4$ & $21 r v$ \\
\hline
\end{tabular}

From the table above it is known that the death of the Prophet Muhammad, that is, on Monday, 14 Rabbi al-Awwal $11 \mathrm{H}$ which coincided with June 8, 632 AD

After the above calculation, the chronological consistency of important events, namely the birth and death of the Prophet in the Hijri calendar can be seen from the exact results of the calculation by looking at the number of days with the age of the Prophet Muhammad. The difference in calculation of the Islamic calendar with the Islamic calendar on the age of the Prophet is done by looking at the difference in each date according to two calendar types, 22,679.4 days ${ }^{62}$ according to the Hijri calendar and $22,678.5$ days $^{63}$ according to $\mathrm{BC}$. Thus it can be concluded that the birth of the Prophet Muhammad saw occurred on Monday Legi, 14 Rabi'ul Awwal 53 BH (5 May 570 AD) and the death of the Prophet Muhammad saw occurred on Monday Legi, 14 Rabi'ul Awwal 11 H (8 June 632 AD).

\footnotetext{
${ }^{62}$ In the Hijri calendar calculation it is known that 64 years 0 months 4 days multiplied by 354.367068 days $(1$ year $=12 \times 29.530589)=64 \times 354.367068=22,679.4$ days.

${ }^{63}$ In the Solar calendar calculation, it is known that 62 years 1 month 3 days multiplied by 365.256360 days $(1$ year $=365.25)=(62 \times 365.25)+30+3$ days $=22,678.5$ days.
} 


\section{E. Bibliography}

Abdurrahman, Dudung. Metodologi Penelitian Sejarah Islam. Yogyakarta: Penerbit Ombak, 2011.

Abu Muhamad Abdul Malik bin Hisyam Al-Muafiri. Sirah Nabawiyah Ibnu Hisyam Jilid I. Edited by terj. Fadhli Bahri. Beirut: Darul Fikr, 1994.

Ahmad, Noor. Risalah Al-Falak Nur Al-Anwar. Kudus: Madrasah TBS, 1986.

Al-Bukhari, Muhammad bin Ismail Abu Abdullah. Al-Jami' Al-Shahih AlMukhtashor. Beirut: Dar Ibn Katsir, 1987.

—. Al-Jami' As-Shahih Al-Mukhtashar. Beirut: Dar Ibn Katsir, 1987.

Al-Maghluts, Sami bin Abdullah. Atlas Agama Islam: Menelusuri Bukti-Bukti Konkret Yang Mengungkapkan Kemuliaan dan Kebenaran Islam melalui Peta dan Foto. Edited by Abdul Rosyid Masykur. Terj. Fuad. Jakarta: Almahira, 2009.

Ali, Jawwad. Sejarah Arab Sebelum Islam (Geografi, Iklim, Karakteristik, dan Silsilah). Edited by Khalifurrahman Fath. Tangerang: PT Pustaka Alvabet, 2018.

Almujalli, Hussam. "The Relationship between the Prophet Muhammad and the Quran." Journal of Islamic Studies and Culture 2, no. 4 (2014): 1-5. https://doi.org/10.15640/jisc.v2n4a1.

Anwar, Syamsul. Interkoneksi Studi Hadis dan Astronomi. Yogyakarta: Suara Muhammadiyah, 2011.

Arfa, Faisar Ananda, Syafruddin Syam, dan Muhammad Syukri Albani Nasution. Metode Studi Islam: Jalan Tengah Memahami Islam. Depok: PT. Raja Grafindo Persada, 2015.

Asqalani, Ibnu Hajar Al. Fathul Bari. Jakarta: Pustaka Azzam, 2007.

Azhari, Susiknan. Ilmu Falak: Perjumpaan Khazanah Islam dan Sains Modern. Yogyakarta: Suara Muhammadiyah, 2004.

Baihaqi, Abu Bakar Ahmad bin Husain. Dalail An-Nubuwwah Wa Ma'rifatu Ahwal Shohibi as-Syarifah. Beirut Libanon: Dar al-kutubal-alamiyah, 2002.

Bakri, Syamsul. Peta Sejarah Peradaban Islam. Yogyakarta: Fajar Media Press, 2011.

Butar-Butar, Arwin Juli Rakhmadi. Esai-Esai Astronomi. Medan: OIF UMSU, 2015.

Djamaluddin, Thomas. "Konsistensi Astronomis Kalender Hijriah," 2010. https://tdjamaluddin.wordpress.com/2010/04/23/konsistensi-historis-astronomiskalender-hijriyah/. 
- "Konsistensi Historis-Astronomis Kalender Hijriyah," 2010. https://tdjamaluddin.wordpress.com/2010/04/23/konsistensi-historis-astronomiskalender-hijriyah/.

Gates, Matthew. "Stellarium." USA: Free Software Foundation, Inc, 2000. http://www.stellarium.org.

Haekal, Muhammad Husain. Sejarah Hidup Muhammad. Cet. ke-2. Jakarta: PT. Mitra Kerjaya Indonesia, 2003.

Hambali, Slamet. Almanak Sepanjang Masa: Sejarah Sistem Penanggalan Masehi, Hijriyah dan Jawa. Edited by Abu Rokhmad. Semarang Indonesia: Program Pascassarjana IAIN Walisongo, 2011.

Hamid, Zaid Husen. Kisah 25 Nabi dan Rasul. Jakarta: Pustaka Amani, 1995.

Hideyuki Ioh. "The Calendar in Pre-Islamic Mecca." Journal of Arabica 61 (2014).

Hitti, Phillip K. History of the Arabs: From the Earliest Times to the Present. Edited by R. Cecep Lukman Yasin dan Dedi Slamet Riyadi. Jakarta: PT Serambi Ilmu Semesta, 2014.

Ibrahim, Salamun. Ilmu Falak: Cara Mengetahui Awal Bulan, Awal Tahun, Musim, Kiblat dan Perbedaan Waktu. Cet. ke-3. Surabaya: Pustaka Progressif, 2003.

Ishaq, Ibnu. The Life of Muhammad. Edited by A. Guillaume. New York: Oxford University Press, 1967.

Izzuddin, Ahmad. Ilmu Falak Praktis (Metode Hisab-Rukyat Praktis dan Solusi Permasalahannya). Semarang: PT. Pustaka Rizki Putra, 2012.

Jannah, Sofwan. Kalender Hijriyyah-Masehi 150 Tahun: 1364-1513 H (1945-2090 M). Yogyakarta: UII Press, 1994.

Kemenag. Ephemeris Hisab Rukyat 2019. Jakarta: Direktorat Urusan Agama dan Pembinaan Syariah Direktorat Jendral Bimas Islam Kementerian Agama RI, 2019.

Maghluts, Sami bin Abdullah bin Ahmad. Athlas Tarikh Al-Anbiya Wa Ar-Rusul. Edited by Terj. Qasim Shaleh. Cet. ke-2. Jakarta: Almahira, 2009.

McPartlan, Maurice A. "The Contribution of Qur' an and Hadit to Early Islamic Chronology." University of Durham, 1997.

Meeus, Jean. Astronomical Tables of the Sun, Moon, and Planets. USA: WillmannBell, Inc, 1983.

Mitchell Beazley. Philip's Astronomy Encyclopedia: A Comprehensive and Authoritative A-Z Guide to the Universe. London: Octopus Publishing Group, 2002. 
Mosley, John. "Stary Night Pro Plus.” Canada: Imaginova Crop, 2004. www.starynight.com.

Muhammadiyah, Majelis Tarjih dan Tajdid PP. Pedoman Hisab Muhammadiyah. Yogyakarta: Majelis Tarjih dan Tajdid PP Muhammadiyah, 2009.

Naisaburi, Abul Husain Muslim bin al-Hajaj. Shahih Muslim. Beirut: Dar al-Fikr, n.d.

Nasir, Bachtiar. Tadabur Al-Qur'an Panduan Hidup Bersama Al-Qur'an. Jakarta: Gema Insani, 2016.

Odeh, Mohammad. "Islamic Cresents' Observation Project," 2013. http://www.icoproject.org/accut.html \%0A.

Qutb, Sayyid. Tafsir fi Zhilalil-Qur'an Jilid 12. Jakarta: Gema Insani, 2001.

Rahman, Afzalur. Ensiklopedi Muhammad Sebagai Nabi. Bandung: Pelangi Mizan, 2009.

Rais, Heppy El. Kamus Ilmiah Populer: Memuat Berbagai Kata dan Istilah dalam Bidang Politik, Sosial, Budaya, Sains dan Teknologi, Psikologi, Kedokteran, Pendidikan. Cet. 1. Yogyakarta: Pustaka Pelajar, 2012.

Rohmad, Muhammad Ali. Potret Pemikiran dan Peradaban Islam. Yogyakarta: Kaukaba Dipantara, 2015.

Shihab, M. Quraish. Membaca Sirah Nabi Muhammad Saw dalam Sorotan AlQur'an dan Hadits-Hadits Shahih. Cet. ke-. Jakarta: Lentara Hati, 2014.

—. Tafsir Al-Misbah: Pesan, Kesan, dan Keserasian Al-Qur'an. Vol. 15. Jakarta: Lentara Hati, 2009.

—. Wawasan Al-Qur'an: Tafsir Tematik atas Pelbagai Persoalan Umat. Bandung: Mizan Media Utama, 2007.

Siswanto, Joko. Orientasi Kosmologi. Yogyakarta: Gadjah Mada University Press, 2005.

Syaikh, Abdullah bin Muhammad bin 'Abdurrahman bin Ishaq Alu. Tafsir Ibnu Katsir Jilid 3. Bogor: Pustaka Imam Asy-Syafi' i, 2004.

Syaikh Shafiyyurrahman Al-Mubarakfuri. Ar-Rahiq Al-Maktum Bahtsun fis Siratin Nabawiyyat 'ala Shahibiha Afdhalush Shalati Was Sallam. Beirut: Dar Ehia AlTourath Al-Arabi, n.d.

Syalabi, A. Sejarah dan Kebudayaan Islam 1. Jakarta: Pustaka Al Husna Baru, 2003.

Wafiyah. Sirah Nabawiyah. Yogyakarta: Ombak, 2013.

Yatim, Badri. Sejarah Peradaban Islam. Jakarta: Rajawali Pers, 2008. 
Zayd, Ahmed Abu. The Life of The Prophet: Correction of The Fallacies in the Encyclopedia of Islam. Morocco: ISESCO, 2003. 